\title{
Positive Selection
}

National Cancer Institute

\section{Source}

National Cancer Institute. Positive Selection. NCI Thesaurus. Code C71257.

The selective retention of a population of desired cells through recognition of cells bearing specific characteristics. 